\title{
Proposed Revision to the Federal Reserve's Discount Window Lending Programs
}

Brian F. Madigan and William R. Nelson, of the Board's Division of Monetary Affairs, prepared this article. The proposal discussed here incorporates contributions from many other Board and Reserve Bank staff members.

The Board of Governors' Regulation A currently authorizes the Federal Reserve Banks to operate three main discount window programs: adjustment credit, extended credit, and seasonal credit. On May 17, 2002, the Board published for public comment a proposed amendment to Regulation A that would establish two new discount window programs called primary credit and secondary credit as replacements for adjustment and extended credit. ${ }^{1}$ The proposed amendment is intended to improve the functioning of the discount window and the money market more generally. The Board also requested comment on the continued need for the seasonal program but did not propose any substantive changes to the program.

According to the proposal, primary credit would be available for very short terms, ordinarily overnight, to depository institutions that are in generally sound financial condition. The interest rate on primary credit would usually be above short-term market interest rates, including the federal funds rate, as opposed to the current situation in which the discount rate (the interest rate for adjustment credit) is typically below money market interest rates.

Eliminating the existing incentive for depository institutions to borrow from the window to exploit the typically positive spread should substantially reduce the administration necessary for each discount window loan. In particular, borrowers of short-term primary credit would no longer be required to have exhausted other sources of funds before turning to the window nor be prohibited from borrowing to fund sales of federal funds. The reduction in administrative burden should help encourage depository institutions to turn to the discount window when money markets tighten significantly and should thereby

1. The proposed amendment to Regulation $A$ and request for comment can be found at www.federalreserve.gov/boarddocs/press/ bcreg/2002/20020517/default.htm. The Federal Register notice, 67 Fed. Reg. 36,544, was published on May 24, 2002. improve the ability of the window to serve as a marginal source of reserves for the overall banking system and a backup source of liquidity for individual depository institutions. Secondary credit would be available, subject to Reserve Bank approval and monitoring, for depository institutions that did not qualify for primary credit. As required by law, all types of discount window loans would have to be backed by adequate collateral.

The primary credit program would be broadly similar to mechanisms adopted by many other major central banks to provide credit at the margin at an above-market interest rate. Adoption of the proposal would not entail a change in the stance of monetary policy. It would not require a change in the Federal Open Market Committee's (FOMC) target for the federal funds rate and would not affect the level of market interest rates more generally.

\section{BACKGROUND}

\section{Functions of the Discourt Window}

In implementing monetary policy, the Federal Reserve employs open market operations as the principal source of reserves to the banking system and currency to the public and as the principal means of effecting short-run adjustments in reserves. In this context, discount window credit has two main roles. First, it acts as a short-run safety valve for the overall banking system by making additional reserves available when the aggregate supply of reserves provided through open market operations falls short of demand, thereby preventing an excessive tightening of money market conditions. Second, it enables depository institutions that are financially sound but have experienced an unexpected shortage of reserves or funding to make payments while avoiding overdrafts on their accounts at Federal Reserve Banks or shortfalls in meeting their reserve requirements.

These discount window functions have been performed primarily by the adjustment credit program. Adjustment credit is extended at the basic discount 


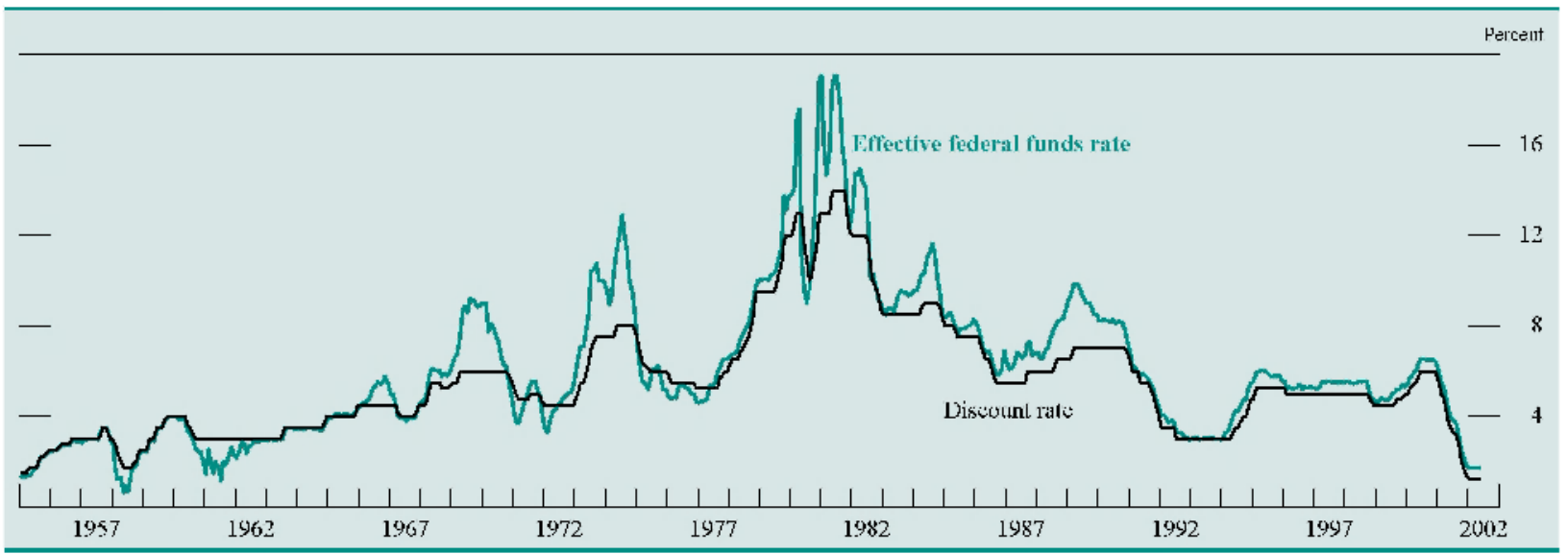

NoTE. The data are monthly and extend through May 2002.

rate, which over the past decade has typically been 25 to 50 basis points below the usual level of overnight market interest rates, as indexed by the federal funds rate (chart). ${ }^{2}$ Despite the below-market discount rate, the volume of adjustment credit has usually been relatively small, in part because the Federal Reserve has sought to prevent an uncontrolled expansion of the supply of reserves and a misallocation of credit by requiring that depository institutions borrow only to meet short-term needs and first exhaust other reasonably available sources of funds.

Under the proposed revision, the functions currently performed by adjustment credit would be performed largely by primary credit. Primary credit would be the principal backup source of reserves for the system and of liquidity for individual depository institutions that are in generally sound financial condition. Under the proposed arrangements, depository institutions would have the incentive to seek out lower-priced alternatives on their own initiative before requesting higher-priced primary credit. Because the interest rate on primary credit would be above the target federal funds rate and because the funds rate usually is close to its target, the aggregate volume of primary credit would be expected to be low." But the volume would be low because of a pricing differential not because administration by Federal Reserve Banks would limit the amount of borrowing.

Besides serving as a marginal source of aggregate reserves to the market and a backup source of liquidity to sound depository institutions, the discount window can also, at times, serve as a useful tool for promoting financial stability by providing temporary funding to depository institutions that are experiencing significant financial difficulties. The provision of central bank credit can help guard against the sudden collapse of depository institutions by addressing liquidity strains while an institution is making a transition to sounder footing. Discount window credit can also be used to facilitate an orderly closure of a failing institution when consistent with least-cost resolution of the failure. An institution obtaining credit in such situations must be monitored appropriately to ensure that it does not take excessive risks in an attempt to return to profitability or use central bank credit in a way that would increase costs to the deposit insurance fund of resolving the institution if a resolution ultimately became necessary. ${ }^{4}$ Historically, the need for such loans to troubled banks has been met by extended credit; under the proposed revision, it would be met by secondary credit.
2. Over the Federal Reserve's first fifty years, the discount rate was generally equal to or higher than short-term market interest rates. The relationship changed in the mid-1960s, and the pattern established at that time has continued over most of the nearly four decades since then. The historical record indicates that the reversal at that time reflected macroeconomic policy considerations rather than a judgment that such a rate alignment was most suitable for operation of the discount window.

3. The proposal for a primary credit program is unrelated to the Federal Reserve System's consideration of alternative assets as substi- tutes for Treasury securities in its portfolio that was discussed in the FOMC minutes of January 30-31, 2001. The minutes of the meeting are available at www.federalreserve.gov/fomc/minutes $/ 20010131 . \mathrm{htm}$. Because the volume of primary credit outstanding ordinarily would be small, primary credit could not be a substitute for Treasuries as a major asset in the System portfolio.

4. Lending under such circumstances may be subject to the guidelines on lending to troubled institutions imposed by the Federal Deposit Insurance Corporation Improvement Act (FDICIA) of 1991. 


\section{Shortcomings of Current Lending Programs Addressed by Proposal}

The below-market interest rate on adjustment credit causes several significant problems. The incentive for depository institutions to exploit the below-market rate means that borrowing requests are subject to considerable administration. Such administration may involve a review of every prospective borrower's funding situation to establish at least a presumption that other reasonably available sources of funds have been exhausted, that the purpose of the borrowing is appropriate, and that the credit will not be used for arbitrage. Because such evaluations necessarily are subjective, achieving consistency in credit administration across the System's twelve Reserve Banks is difficult. Also, the process of obtaining information on depository institutions' funding situations can be somewhat burdensome to the institutions, likely making them reluctant to turn to the window. In addition, the rules for the use of discount window credit necessitated by the below-market rate have proved difficult to formulate and explain, and depository institutions have often cited uncertainty about their borrowing privileges as a reason for their reluctance to borrow. Depository institutions have been required first to

\section{Primary Credit: An Improved Safety Valve for Releasing Significant Market Pressures}

A key function of adjustment credit is to serve as a safety valve for the bank reserves market. On any given day, the aggregate volume of reserves provided through open market operations can fall short of the amount demanded as a result of fluctuations in various factors that affect the supply of: or demand for reserves. Borrowing from the discount window creates additional reserves, so the willingness of: depository institutions to turn to the discount window when such shortfalls occur governs the extent of the effects of the shortfalls on money market interest rates. If depository institutions are very reluctant to use the window, they bid vigorously for funds in the market, pushing money market rates, especially the overnight federal funds rate, up sharply. But if depository institutions are quite willing to use the window, the increase in the funds rate may be much more modest.

Average borrowing on days on which the federal funds rate was high, 1989-2001

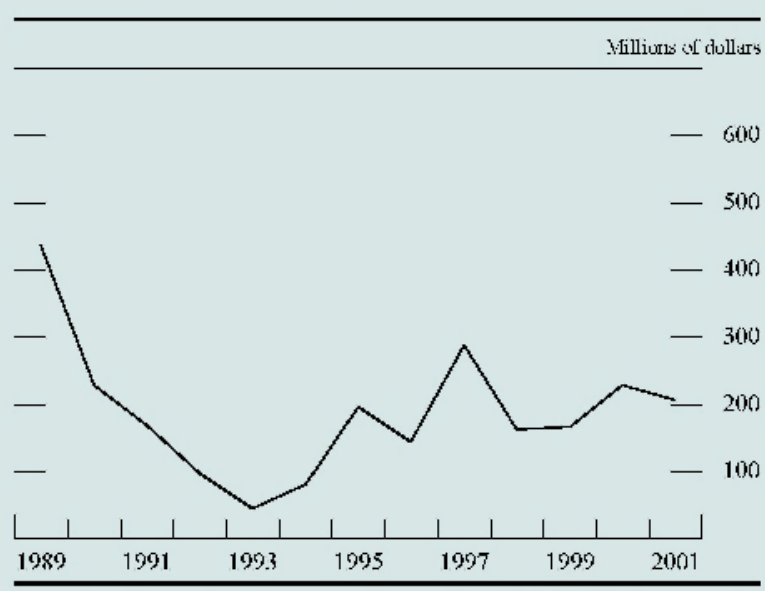

NoTE. Average adjustment credit borrowing by large banks on days on which the federal funds rate was 25 to 200 basis points above the targeted federal funds rate at the close. The data are annual.
The willingness of institutions to use the window and the associated effects of a shortfall in reserves on money market interest rates have varied considerably over time. One gauge of this willingness is the average level of adjustment credit extended to large banks on days when the funds rate tightens moderately, exceeding the FOMC's target by 25 to 200 basis points at the close (chart).

During the early $1990 \mathrm{~s}$, that average was quite low. At its low point, reached in 1993, adjustment borrowing on moderately tight days averaged just $\$ 45$ million. In those years, a number of banking institutions experienced significant financial difficulties. As a result, many banks, even healthy institutions, were concerned that their borrowing would be viewed by other market participants as a sign of financial weakness. Such perceptions could result in serious difficulties for the institution (or exacerbate existing problems). Even though the Federal Reserve holds information about borrowing by individual banks in the strictest confidence, market participants have at times tried to infer which banks might be borrowing through knowledge of which banks were bidding for funds in the market late in the day and from aggregate data published by the Federal Reserve.

In recent years, institutions have become somewhat more willing to use the window, with adjustment borrowing on moderately tight days exceeding $\$ 200$ million on average in 2000 and 2001. The increased willingness has undoubtedly been largely due to the improved condition of the industry. Still, institutions have on occasion been willing to pay quite high rates in the market rather than turn to the discount window, suggesting that some institutions remain reluctant to borrow. Even if the proposed change in discount window structure does not completely eliminate that reluctance, it should still help damp late-day spikes in the federal funds rate. With no restrictions on the re-lending of funds obtained through the program, institutions that are willing to borrow at the window should have an incentive to borrow primary credit and lend in the funds market to other institutions that might have some residual reluctance to turn to the discount window. 
seek funds in the market before seeking discount window credit. This requirement may make them reluctant to borrow because turning to the window after signaling their need for funds to the market could be seen as a sign of weakness, particularly during episodes of financial stress. The reluctance to use discount window credit stemming from these factors has limited the effectiveness of the discount window in buffering shocks to money markets. (See box "Primary Credit: an Improved Safety Valve for Releasing Significant Market Pressures.")

The establishment of a lending program with an above-market rate would sharply reduce the need for the administration of the window. Reduced administration would encourage greater uniformity in the administration of the discount window across Federal Reserve Districts. It should also mitigate institutions' reluctance to borrow when money markets tighten sharply by minimizing Reserve Bank questioning, by significantly increasing the comprehensibility of the rules regarding credit extension, and by eliminating the requirement that institutions first attempt to secure funds elsewhere. Furthermore, the proposed changes should appreciably reduce depository institutions' concern that borrowing will be perceived as a sign of weakness, as only financially sound institutions will have access to primary credit.

The proposal to adopt a primary credit program is also related to the Federal Reserve's ongoing planning for contingencies. Having a means of preventing an undue tightening of money markets during a financial market crisis, such as that following the terrorist attacks on September 11, 2001, would be useful in the event that depository institutions' demands for excess reserves rise sharply; disruptions inhibit the flow of funds through the banking system, particularly late in the day; or the Federal Reserve's ability to carry out open market operations is impaired. If, as is intended, the primary credit facility significantly reduces the reluctance of depository institutions to use the discount window, the Federal Reserve should be able to cap the federal funds rate near its target during a crisis by reducing the primary discount rate to a level close to the target.

\section{SPECIFICATIONS OF THE PROPOSED NEW TYPES OF CREDIT. \\ Primary Credit}

As the replacement for adjustment credit, primary credit would be available only to generally sound depository institutions, ordinarily with little or no administrative burden on the borrower. It would typically be extended for very short terms (usually overnight) but could be extended for up to a few weeks if the lending Reserve Bank determines that the institution is in generally sound condition and cannot obtain such credit in the market on reasonable terms (those qualifying for longer-term loans would in most cases be relatively small institutions that lack access to national money markets).

\section{Interest Rate}

Under the proposal, the primary discount rate would be changed through the same discretionary procedure currently followed for setting the basic discount rate: The boards of directors of the Federal Reserve Banks would establish a primary discount rate, as well as other discount rates, every two weeks subject to review and determination by the Board of Governors, as required by the Federal Reserve Act. The primary discount rate would not be set according to a formula but would presumably move broadly in line with the target federal funds rate, much as the basic discount rate does currently.

The proposal suggests that when the program begins, the boards of directors of the Federal Reserve Banks would initially establish, subject to the statutorily required review and determination by the Board of Governors, the primary discount rate at a level 100 basis points above the FOMC's then-prevailing target for the federal funds rate. That level would likely place the primary discount rate somewhat above the cost of alternative short-term funds for eligible depository institutions, except in circumstances of unusually tight money markets or funding needs arising very late in the day. (Such a spread would also be similar to the spreads employed by other central banks. See box "Experience of Other Central Banks.")

A substantial spread would encourage depository institutions to borrow only to meet short-term, unforeseen needs. Too wide a spread, however, would mean that the federal funds rate could, at times, rise to undesirably high levels above the FOMC's target. Notably, if the primary discount rate were to fall close to or below the target federal funds rate, the Reserve Banks would again need to restrict the use of discount window credit, eliminating the advantages of primary credit relative to adjustment credit. Although the proposal tentatively recommends an initial spread of 100 basis points, public comment will help inform both the Federal Reserve's choice of that initial spread and the subsequent establishment of primary discount rates. An aspect of the proposal 
is that the primary discount rate could be lowered in an emergency, thereby helping to ensure that the federal funds rate is capped at a level that would facilitate the continued functioning of financial markets during crises.

\section{Eligibility}

Only depository institutions judged by the lending Reserve Bank to be generally sound would be eligible for primary credit. At the inception of the new

\section{Experience of Other Central Banks}

The central banks of nearly all industrialized countries have standing lending facilities that make collateralized loans at an above-market rate. ' Such facilities are sometimes called "Lombard" facilities after Lombardkredit, the German term for a collateralized loan and for the loans made at an above-market rate by the Swiss National Bank and, before the formation of the European Central Bank (ECB), by the Bundesbank (the central bank of: Germany). ${ }^{2}$ In 1999 , the ECB was opened with a Lombard facility; in 1996, the Bank of Canada restructured its facilities to include an overdraft facility that acts as a Lombard facility; and in 2001, the Bank of Japan adopted

1. The major exceptions are the Federal Reserve and the Bank of England. If liquidity is needed, the Bank of England instead conducts a late-afternoon overnight repurchase agreement (repo) operation normally at 100 basis points above the prevailing official repo rate. It also has the option of opening a late lending facility for the clearing banks after the markets have closed. The applicable repo rate for the late lending facility ranges between the official repo rate and 150 basis points above the repo rate, depending on market conditions.

2. The Lombardy region of Northern Italy was an important center of finance in the Middle Ages. The word "Lombard" came to mean banker or moneylender (also pawnbroker)-hence such terms as lombardkredit, Lombard facility, and Lombard Street, the London address that in the nineteenth century was the center of English banking. In his 1873 book, Lombard Street: A Description of the English Money Market (New York: E.P. Dutton, 1910), Walter Bagehot famously recommends that in response to a financial panic, the central bank lend freely at a penalty rate (chap. 7, p. $198 \mathrm{ff}$.). The application of the term "Lombard facility" to that practice has to do, however, with the medieval origins of "Lombard" rather than, as is sometimes thought, with the name of Bagehot's book or Lombard Street itself. a Lombard facility. Other central banks that have employed Lombard facilities include those in Austria, Belgium, France, Italy, and Sweden. These facilities typically have extended short-term credit with few restrictions on the borrowing institution's funding situation or use of the proceeds. Lombard rates have varied from 25 to 200 basis points above the central bank's target policy rate or related money market rates. The ECB has generally set the marginal lending rate (the rate on its Lombard facility) 100 basis points above the refinancing rate (its target policy rate) (chart).

Discussions with staff members of these central banks indicate that Lombard facilities that are a part of monetary policy operations similar to those of the Federal Reserve have been very effective in setting an upper limit on market rates. For example, after the Bundesbank removed certain limits on Lombard loans and began to actively target the overnight interest rate, overnight market rates never rose above the ceiling. Similarly, since the inception of the ECB in 1999, the daily average interbank rate in the euro area has not risen above the ECB's marginal lending rate, while intraday data indicate that within-the-day highs of euro-area interbank rates have only rarely exceeded the marginal lending rate and by very little. The recent experience of the Bank of Canada indicates that its lending arrangement has also been an effective ceiling for rates. It is too soon to determine whether the Bank of Japan's Lombard facility will effectively cap overnight money market rates.

European Central Bank benchmark interest rates, 1999-2002

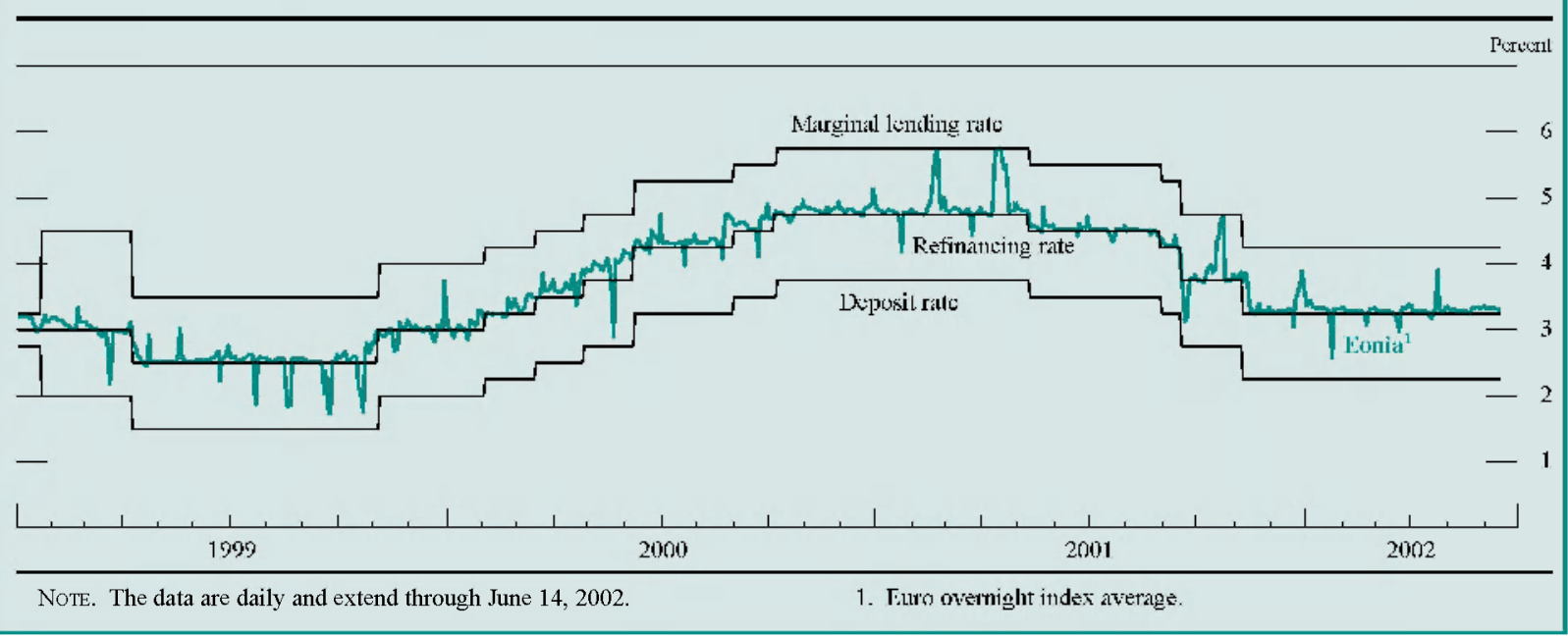


program, the Reserve Banks would classify each depository institution with a borrowing agreement already on file as either eligible or ineligible for primary credit and would notify the institution of its status. New applicants for Federal Reserve credit would be notified of their eligibility once they filed borrowing documents. Institutions would also be notified promptly of any change in their eligibility. The Federal Reserve would treat institutions' eligibility or ineligibility as confidential.

The Reserve Banks would adopt uniform guidelines for judging institutions' degree of financial soundness and thus their eligibility for primary credit. A general principle to be reflected in the guidelines would be that primary credit should be viewed as an attractive source of funds mainly when money markets tighten significantly, pushing overnight market interest rates at least to the level of the primary discount rate. That is, all eligible institutions should usually face a cost of overnight funds in the marketplace somewhat below the primary discount rate. Because only generally sound depository institutions would be eligible to obtain primary credit, the establishment of eligibility guidelines could also help reduce the concerns of depository institutions that borrowing at the discount window would be viewed as a sign of weakness; as noted previously, such concerns have at times severely limited the willingness of depository institutions to borrow, even when money markets were extremely tight.

The guidelines for determining eligibility would be based primarily on supervisory ratings, though supplementary information, including ratings issued by major rating agencies, market spreads on subordinated debt, information from supervisory exams in progress, and other news since the last exam, would also be considered. The Reserve Banks would initially adopt guidelines along the following lines: Domestically chartered depository institutions with CAMELS ratings of 1 or 2 and branches and agencies of foreign banking organizations with Strength of Support Assessment (SOSA) of 1 would be eligible for primary credit unless supplementary information suggested that the institution's financial condition had deteriorated since its last examination. ${ }^{5}$ Institutions rated CAMELS 3 or SOSA 2 would be eligible for primary credit if supplementary information suggested that they were generally sound, but the funding situation of such institutions seeking credit would

5. CAMELS (Capital, Assets, Management, Earnings, Liquidity, and Sensitivity to market risk) ratings are set on a scale of 1 through 5 , with 5 representing the highest degree of supervisory concern. SOSA rankings are set on a scale of 1 through 3 , with 3 representing the highest degree of supervisory concern. be reviewed and monitored. Institutions rated CAMELS 4 or SOSA 3 would not be eligible for primary credit except in rare circumstances, such as when an ongoing examination indicated a substantial improvement in condition. Credit extensions to ineligible CAMELS 4 and SOSA 3 institutions as well as to CAMELS 5 institutions would be made under the proposed secondary credit program, described later. Based on the proposed guidelines and the current distribution of supervisory ratings, most depository institutions would be judged eligible for the primary credit program.

These criteria are consistent with the intent of the guidelines for discount window lending contained in the Federal Deposit Insurance Corporation Improvement Act in that lending to troubled institutions would be closely monitored. The criteria are also consistent with the guidelines used by Federal Reserve Banks to determine institutions' access to daylight credit as set forth in the Federal Reserve's Payments System Risk Policy. In general, depository institutions that qualify for access to daylight credit would be eligible for primary credit, and those that do not would be restricted to secondary credit.

\section{No Requirement Regarding Exhaustion of Funds}

The requirement in Regulation A that depository institutions exhaust reasonably available alternative sources of funds before obtaining adjustment credit would be dropped. The removal of this requirement is consistent with the overall reduction in discount window administration that the Federal Reserve would be seeking under this program. As an important consequence, depository institutions would be free to sell federal funds to others while obtaining primary credit as long as those activities were consistent with safe and sound banking practices. In addition, allowing depository institutions to resell the proceeds of primary credit loans would enhance the ability of the primary credit rate to serve as a cap on the federal funds rate when money markets tighten. For that reason, the Federal Reserve would welcome financially sound institutions' engagement in such transactions if the institutions judge that the transactions would be in their financial interest.

\section{Collateral}

Under the proposal, collateral policies would be unchanged. As required by the Federal Reserve Act, all borrowing would be collateralized to the satisfaction of the lending Reserve Bank. Federal Reserve 
Banks would continue to accept a broad range of financial assets as collateral for discount window loans.

\section{Reserve Bank Discretion to Lend or Not Lend}

The main purpose of the proposed primary credit program is to make short-term credit available as a backup source of liquidity to generally sound institutions. Reserve Banks would retain the discretion not to lend in circumstances that they apprise are inconsistent with that purpose.

\section{Secondary Credit}

Secondary credit, the proposed replacement for extended credit, would be designed for depository institutions that do not qualify for primary credit. Because some institutions currently eligible for adjustment credit would not qualify for primary credit, secondary credit would potentially be used more often than extended credit has been, particularly in recent years, and the program would be designed to recognize the somewhat broader class of borrowing situations that would be covered under it. Specifically, secondary credit might be extended to meet temporary funding needs of an institution if, in the judgment of the Reserve Bank, such a credit extension would be consistent with the institution's timely return to reliance on private funding sources. Also, a Reserve Bank may extend secondary credit if, in cooperation with the Federal Deposit Insurance Corporation and consistent with a least-cost resolution, the Reserve Bank determines that such credit would facilitate the orderly resolution of serious financial difficulties of the borrowing institution. The change in the name of the program is intended in part to eliminate the focus on longer-term credit extensions implied by the term "extended credit."

The interest rate on secondary credit would be set by formula at 50 basis points above the primary discount rate. The setting of the interest rate at a level above the rate on primary credit - and therefore even further above the target federal funds rate-reflects the less-sound condition of borrowers of secondary credit.

\section{Seasonal Credit}

The proposal recommends no substantive change to the seasonal credit program. Seasonal credit would remain available to small and medium-sized institutions that experience significant seasonal swings in their loans and deposits. The rate on seasonal credit would continue to be the average of the effective federal funds rate and the secondary market interest rate on large ninety-day certificates of deposit for the previous reserve maintenance period. Because such a rate would almost always be less than the primary discount rate, it would be necessary to remove from Regulation A the stipulation that the seasonal credit rate be at least as high as the basic discount rate.

The seasonal credit program was originally designed to address the difficulties that relatively small banks experiencing substantial intra-yearly swings in funding needs faced because of a lack of access to the national money markets. However, funding opportunities for smaller depository institutions have expanded considerably over the past few decades as a result of deposit deregulation and the general development of financial markets. These changes call into question the continued need for the seasonal program. The proposal seeks specific public comment on whether small depository institutions still lack reasonable access to funding markets, on the continued need for the seasonal lending program, and on the appropriate setting of the seasonal credit discount rate, particularly in view of the proposed establishment of a primary credit program with an abovemarket interest rate.

\section{NEXT STEEPS}

The Board is seeking public comments on all aspects of the proposal. The comment period, extending for ninety days from date of publication, ends August 22, 2002. Following an analysis of the comments, the stafe will present a revised proposal to the Board. If the Board votes to revise the Federal Reserve's lending programs, the changes will take place once internal procedures are modified, a process that could take several months, and depository institutions are made familiar with the new procedures. 